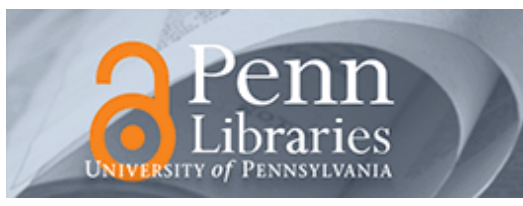

University of Pennsylvania ScholarlyCommons

Wharton Pension Research Council Working

Papers

Wharton Pension Research Council

$1-1-2010$

\title{
Implications of the Financial Crisis for Long Run Retirement Security
}

Olivia S. Mitchell

The Wharton School, University of Pennsylvania, mitchelo@wharton.upenn.edu

Follow this and additional works at: https://repository.upenn.edu/prc_papers

Part of the Economics Commons

Mitchell, Olivia S., "Implications of the Financial Crisis for Long Run Retirement Security" (2010). Wharton Pension Research Council Working Papers. 188.

https://repository.upenn.edu/prc_papers/188

This paper is posted at ScholarlyCommons. https://repository.upenn.edu/prc_papers/188

For more information, please contact repository@pobox.upenn.edu. 


\title{
Implications of the Financial Crisis for Long Run Retirement Security
}

\begin{abstract}
Managing retirement risk has become extraordinarily difficult in this era of financial turmoil, global interlinkages, and global population aging. It is particularly fraught since consumers must now engage in longterm contracts with themselves, employers, financial institutions, and governments, regarding the future of retirement financing. Moreover, these agreements will need to remain in force extraordinarily long, for fifty or even one hundred years into the future. This note reviews what institutions and instruments that have a successful track record in retirement risk management over such a long time horizon.
\end{abstract}

\section{Keywords}

Retirement, pension, government, longevity, risk, insurance, management, insurance, retirees, annuities

\section{Disciplines}

Economics 


\section{Implications of the Financial Crisis \\ for Long Run Retirement Security}

Olivia S. Mitchell

January 2010

\section{PRC WP2010-02 \\ Pension Research Council Working Paper \\ Pension Research Council \\ The Wharton School, University of Pennsylvania \\ 3620 Locust Walk, 3000 SH-DH \\ Philadelphia, PA 19104-6302}

Tel: 215.898.7620 Fax: 215.573.3418

Email: prc@wharton.upenn.edu

http://www.pensionresearchcouncil.org

Opinions and conclusions are solely those of the author(s) and do not reflect views of the institutions supporting the research, with whom the authors are affiliated, or the Pension Research Council. Copyright 2010 (c) Pension Research Council of the Wharton School of the University of Pennsylvania. All rights reserved. 


\title{
Implications of the Financial Crisis \\ for Long-run Retirement Security
}

\author{
Olivia S. Mitchell
}

\begin{abstract}
Managing retirement risk has become extraordinarily difficult in this era of financial turmoil, global interlinkages, and global population aging. It is particularly fraught since consumers must now engage in long-term contracts with themselves, employers, financial institutions, and governments, regarding the future of retirement financing. Moreover, these agreements will need to remain in force extraordinarily long, for fifty or even one hundred years into the future. This note reviews what institutions and instruments that have a successful track record in retirement risk management over such a long time horizon.
\end{abstract}




\title{
Implications of the Financial Crisis for Long-run Retirement Security
}

\author{
Olivia S. Mitchell ${ }^{1}$
}

This note discusses some of the implications of the financial crisis for retirement systems, now and in the future. My message is straightforward and, I fear, not particularly upbeat: current and future generations of managers and employees will not be able to use the 'old fashioned' model of provisioning for retirement. Instead, the $21^{\text {st }}$ century economy will require an entirely new perspective on retirement risk management. That is, we need to build a new framework that will require public and private partnerships to better educate people about the risks they face, to help them work longer, to create and foster new financial institutions and contracts, and to better regulate products and markets for an aging world.

In what follows, I identify and describe the sources of retirement risk in four realms: individual, institutional, national, and global. Along the way I note several factors that deserve consideration when devising new approaches to retirement risk management.

\section{Individual Retirement Risk}

A conventional view of the life cycle problem is that the consumer must save and invest during youth and middle age, so as to have income and/or assets to live on during the later phase in life, when working has stopped. Pensions play a role in this

\footnotetext{
${ }^{1}$ Mitchell is Professor and Chair of the Insurance and Risk Management Department at the Wharton School, where she also directs the Boettner Center and Pension Research Council.
} 
accumulation and later payout process, as they represent a form of deferred earnings. So too does the buying of property and paying down one's home mortgage. Then, during the decumulation phase of life, the task is to figure out a way to draw down assets in an orderly manner, and not too quickly either, so that one doesn't run out of money.

Yet many problems befall mere mortals when they try to implement a life cycle approach to retirement preparedness. For one thing, many people are woefully financially ignorant and hence quite unlikely to do a good job even evaluating the potential needs. For another, people too often fail to plan and execute any retirement saving plan at all. And last, at least half of the population will outlive their life expectancy - which increases the chances of running out of money. To illustrate the challenges, we have surveyed a wide range of people with questions on financial literacy; here we present results for the "percentage calculation," the "lottery division," and the "compound interest” question. These are worded as follows:

1) If the chance of getting a disease is 10 percent, how many people out of 1,000 would be expected to get the disease? [Percentage Calculation]

2) If 5 people all have the winning number in the lottery and the prize is 2 million dollars, how much will each of them get? [Lottery Division]

3) Let's say you have 200 dollars in a savings account. The account earns 10 percent interest per year. How much would you have in the account at the end of two years? [Compound Interest]

Results appear in Table 1 . On the one hand, almost $84 \%$ of the respondents - who were at the time in their mid-50s - can correctly compute the percentage question. More troubling is the fact that only slightly over half of the Boomers can accurately divide \$2 million by 5 . But of most concern, only $18 \%$ of this nationally representative sample of Americans in their 50's understands compound interest. Of those responding incorrectly, around two-fifths do a simple interest computation, whereas three fifths will either fail to 
answer at all, or get the answer very wrong indeed. This is very troubling given that people in their mid-‘50s have taken out credit cards and student loans, borrowed for car purchases, and taken mortgages. In other words, they've led a financial life, but they obviously do not understand compound interest. This suggests one way we got into the subprime mortgage crisis!

We also find that these three financial literacy questions turn out to be incredibly good predictors of whether middle-aged people plan for retirement, save for retirement, and do well at retirement. While the better educated do better, it appears that only $18 \%$ of those households on the verge of retirement are actually relatively successful at devising retirement plans and executing them, at least mostly. And also, not surprisingly, we also fin that those who succeed at retirement planning are over twice as wealthy as those who do not.

We turn next to longevity risk, another key source of retirement risk to be managed in later life. To explore whether people 'get it,' we ask a nationally representative survey of Baby Boomers what their chances are of living to age 75 and 85 . We do this on the grounds that if people underestimate their anticipated lifespan, they will also be likely to undersave and overconsume in old age. Interestingly, we find that most predict their survival probabilities reasonably well, compared to actuarial tables, when thinking about their chance of being alive at age 75. However, they underestimate the chance of living to be older. Naturally this suggests that many will undervalue the risk of running out of money in old age. We note in passing that UK actuaries pricing longevity risk in insurance contracts are now using age 125, and in the US, age 120. 
Thus for anyone thinking he might not need to plan beyond age 90, the message is that “tail risk” is substantial - that is, the risk of living well beyond your life expectancy.

This leads naturally into a discussion of how one might protect against living too long. A valuable financial tool for this purpose is a payout life annuity, a financial contract that permits the buyer to pool survival risk with others also concerned about the same problem. Specifically, the purchaser will exchange premium payments for a promise from an insurer to pay a benefit until death. Interestingly, this is a market where there is much room for adverse selection: people who buy payout annuities tend to live longer, which is hardly surprising. Therefore insurers must price accordingly, since those who anticipate living long are also those who most demand such payout products.

Notwithstanding the tremendous value of having peace of mind that follows from having a lifetime pension - a lifelong stream of income that will not run out, as long as one lives - there is much current debate about how important annuities should be in future retirees' portfolios. Part of the debate is driven by concern over the health of insurers: some apparently have invested in assets that became impaired in the financial crisis. In the last few years, retirees have been also been attracted to products that allowed buyers to share market gains on the upside, while having guaranteed floor provisions protecting them when the market went down. Whether insurers will need help to make good on these promises is currently under debate. And the observed fragility of AIG, while not originating from its traditional insurance lines, has also cast a shadow over the industry as a whole. To date, some life insurers have received regulatory relief due to their depleted reserves, and others have discussed applying for federal funds. This is a remaining area of concern. 
How can and should households respond to these important, and in the past underestimated, sources of retirement risk? One answer is clearly to save more - a lot more! - since old age can last a very long time. Another is to diversify better and insure with strong and highly-rated institutions that pool risk. And yet another would be to invest in human capital throughout the lifetime, so that people have skills that still command value later in life. Relatedly, if one can work longer, this may offer an additional degree of freedom that could be very useful when other assets fluctuate in value. My research has shown that savings shortfalls are substantially curtailed by just another two, three, or four years of work at older ages. For the younger generation, age 75 might be a good target for early retirement, and later if possible!

\section{Institutional Considerations}

Next we move to consider institutional risk - that is, the possibility that the pension pillar of the retirement edifice might fail. And indeed, in many countries, pensions are in extraordinarily poor condition. Recent media reports have indicated that US corporate as well as public sector pension plans held over $\$ 15$ trillion in assets as of January 2008. The problem was that US pension funds leaned heavily toward equity, and when the market crashed, so too did the plan funding levels. In the public sector, it has been estimated that states and municipalities hold only about 55\% of the money needed to discharge the benefit promises. In what is probably the most discussed and potentially most threatened corporate plan case, we have the General Motors defined benefit pension, currently underfunded by about $\$ 20$ billion according to the government. Corporate plans at least have some protection from the US government in the form of a 
re-insurance entity charged with backstopping corporate pension promises. So if a US company fails with a defined benefit plan, its accrued pension benefits are taken over by PBGC, the Pension Benefit Guaranty Corporation. The UK recently established a similar reinsurer group.

Despite best intentions, however, the governmental reinsurers have also gotten into trouble. In the US, for instance, the PBGC covers the auto, steel, and airline industries, all of which have had troubles. Furthermore the agency's premiums have not been set in accordance with insurance principles, and its assets were invested in the stock market. While the agency currently has sufficient funds to pay benefits to existing retirees, it is not solvent in the longer run, and may require a future TARP-style bailout.

It used to be thought that defined contribution plans offer a preferred alternative to the defined benefit plan's problems, though many now believe otherwise given recent experience. In the US 401(k) plan context, the employer offers a menu of funds available for tax-qualified saving. Sometimes they provide a match to employee contributions. And then members decide how to allocate their own portfolios. If we were all rational and fully informed, we would no doubt do what we should: balance expected risk and return, make independent judgments, diversify, pay close attention to fees and charges. But what do people actually do? The research indicates substantial inertia and lack of investment sophistication. Therefore the new approach is to put in place automatic enrollment and, for those who do not make a fund allocation election, to default them to target maturity date funds. These start the employee in a mix heavier in equities when young, and then they gradually rebalance with age toward a less risky portfolio. These seem quite attractive for the less financially literate, the lower paid, and women. While these are 
likely appealing for the long run, the fact remains that any portfolio heavy with equity in the last year has done very poorly indeed, which may challenge the auto-enrollment strategy into target maturity date funds in the future.

Because of the market downturn, some have begun to argue that guarantees are needed in workers' pension accounts. But guarantees cost, and the more generous the guarantee, the more it costs! In Japan, for example, the 401(k)-type model requires that at least one fund be principal guaranteed - that is, after 40 years, the member is sure to get back at least the money he put in (with a zero rate of return). Our research shows this is relatively easy and inexpensive. But guaranteeing a bond return is not cheap: it could cost an annualized 16 percent of contributions every single year. Thus it may be a good idea to include these in the retirement saving products on offer, but one should not imagine that they can be provided for free.

\section{National Risk Exposures}

Let us move next to national factors influencing retirement risk management. Indeed these are some of the most unpredictable unknowns confronting those trying to plan for retirement. Political risk is always an issue: we need only recall Argentina's recent government takeover of private pension assets, on the argument that retirees would be 'safer' with government IOU's. Globally, it is quite uncertain what the national macroeconomy will look like over the next decade. Yet when deciding whether to quit working, one needs good estimates of inflation, future taxes and transfers, and the availability of medical care, if we are to determine adequacy. But good forecasts are simply not available. 
I illustrate the case by discussing the nation's Social Security program. This system has an insurance aspect, in that higher benefits are paid to those paying in more, and a welfare aspect in that lower earners receive a much greater benefit level. But the US Social Security system is facing some huge problems which will start to become expensive within a mere eight years. The reason is that promised benefits will come to exceed payroll taxes (contributions) within eight years. At that point, something must be done to restore the program to solvency. In the near term, the Social Security system holds Trust Fund bonds which the US government must pay as it backs these with its full faith and credit. But this overlooks the fact that the US government's credit is becoming increasingly strained due to other budgetary demands.

In my work with the bipartisan Commission to Strengthen Social Security, we argued that Social Security's financing problems could be remedied with one simple change, namely a reduction in the benefit growth rate. That is, under current rules, promised future benefits are slated to grow faster than prices, a major factor in the system's insolvency. We showed that this can be remedied it by limiting benefit growth to inflation - no benefit cuts would be required at all, compared to current levels. This single change is actually sufficient to return the system to solvency, and indeed our work showed it would also allow some additional benefit enhancements for the lifetime lowwage. In addition, the Commission was asked by the President to design voluntary personal accounts, which we also did in such a way that it left the system actuarially neutral; that is, it would not cost the system nor benefit it.

Sadly, the Commission's work concluded in a troubled period, just after the 9/11 attacks and when the government's attention had turned to international matters. But even 
though politicians' attention was elsewhere, it is nevertheless essential to undertake reform very soon for this key pillar of the retirement system. The urgency of this message is underscored by the challenges facing another important program for the elderly, namely Medicare, which is the national old-age healthcare system. Indeed it is estimated that the unfunded cost of Medicare comes to around six times that of Social Security, with the combined gap amounting to many times the US gross domestic product. Solving these long-term problems must be given a high priority, not only for retirement risk management, but also for the credible management of government obligations.

\section{Global Risk Considerations}

Last though surely not least, we turn to the topic of global retirement risk management. At the international level, the reality is that remarkably little can be done in the near term to enhance retirement security over the decades to come. Some risks we worry about are things like epidemics: bird flu, Asian flu, and SARS come to mind, for instance. And until recently, many worried that in retirement, Baby Boomers would suddenly redeem their assets and precipitate a global asset meltdown. Sadly we now realize that assets have melted down without the Boomers having caused it by !

The problem with global risk, of course, is that it is mostly non-diversifiable. That is, spreading one's investments around the world for international diversification purposes does not today seem to offer the kind of risk pooling that was once touted. In the past, this is what pay-as-you-go social security systems did: get tomorrow's workers to help pay for those beset by today's financial shocks. But unlike the past, future 
generations are likely to be smaller than in the past so there will be too few workers to support future generations. And there is no formal market where we can trade with those not yet born.

\section{Conclusions}

Managing retirement risk has become extraordinarily difficult in this era of financial turmoil, global interlinkages, and global population aging. It is particularly fraught since we now must make extraordinarily long-term contracts with ourselves, employers, financial institutions, and governments, about retirement financing. Moreover, these agreements will need to remain in force for 50 or even 100 years into the

future. Nevertheless, history reveals few institutions and instruments that have a successful track record over such a long time horizon.

For this reason, we must find ways to become more resilient as individuals, managers, and policymakers, which will require reinventing retirement. Part of the task is to enhance financial literacy and political responsibility. We will also need to save more, invest smarter, and insure better against longevity. Another task will be to develop new products which can be used to hedge longevity and better protect against very long term risks including inflation. But when all is said and done, most of us will simply have to work longer to preserve some flexibility against shocks in the long run. 
Table 1: Financial Literacy Among Early Baby Boomers $(\mathrm{N}=1,984)$

\begin{tabular}{|c|c|c|}
\hline Question Type & Correct (\%) & $\begin{array}{c}\text { Incorrect/Don't } \\
\text { know (\%) }\end{array}$ \\
\hline $\begin{array}{c}\text { Percentage } \\
\text { Calculation }\end{array}$ & 83.5 & 16.0 \\
\hline $\begin{array}{c}\text { Lottery } \\
\text { Division }\end{array}$ & 55.9 & 43.1 \\
\hline $\begin{array}{c}\text { Compound } \\
\text { Interest* }\end{array}$ & 17.8 & 81.7 \\
\hline
\end{tabular}

Notes: Early Baby Boomer sample surveyed in the Health and Retirement study weighted using household weights. Percentages may not sum to 100 due to missing data on a few respondents; values conditional on being asked the question. Source: Adapted from Lusardi and Mitchell, "Financial Literacy: Evidence and Implications for Financial Education” report for the TIAACREF Institute, March 2009. 